\title{
Environmental Allergens: from Asthma to Hay Fever and Beyond
}

\author{
Paul John Beggs ${ }^{1}$
}

Published online: 20 June 2015

(C) Springer International Publishing AG 2015

\begin{abstract}
Climate change has many impacts on environmental allergens and allergic diseases such as asthma and hay fever. Our knowledge of these impacts has grown considerably over the last 2 decades or so, and the last two and a half years in particular have seen a surge in research published on this topic. This report reviews the work published on climate change, allergens and allergic diseases since 1 January 2013. The review focusses on literature published in the peer-review journal literature, although a number of other prominent sources are also examined. Research of particular significance over the past two and a half years or so includes experimental studies that have quantified changes in allergenicity of pollen under combinations of elevated carbon dioxide and drought stress (for ragweed) and ozone (for Timothy grass). Other extensions of the research on this topic include a number of studies that are considering the impacts of climate change on allergic diseases with increasing sophistication and power. The review also considers recent research related to climate change adaptation in the context of impacts on allergens and allergic diseases. In conclusion, the latest research overall reaffirms this impact as one of the most important impacts of climate change on human health.
\end{abstract}

Keywords Allergy $\cdot$ Allergic disease $\cdot$ Pollen $\cdot$ Spore $\cdot$ Temperature $\cdot$ Carbon dioxide

This article is part of the Topical Collection on Climate Change and Human Health

Paul John Beggs

paul.beggs@mq.edu.au

1 Department of Environmental Sciences, Faculty of Science and Engineering, Macquarie University, Sydney, NSW 2109, Australia

\section{Introduction}

Climate change has many impacts on environmental allergens and allergic diseases such as asthma and hay fever. There is now considerable evidence of these impacts occurring in the recent past, the present and into the future. While a number of climatic variables are involved, particularly temperature, with plants being an important source of allergens, the greenhouse gas carbon dioxide $\left(\mathrm{CO}_{2}\right)$ also plays a major role in the observed and projected changes in such allergens.

Perhaps the earliest in-depth review and synthesis of the impacts of climate change on allergens was published a little over a decade ago [1], and the latest just last year [2]. As described in this latest review, there is now evidence for impacts of climate change on respiratory allergens such as those from pollen and mould spores, contact allergens, plant food allergens and insect allergens [2]. With respect to the impacts of climate change on respiratory allergens, resulting primarily from increasing atmospheric carbon dioxide concentration and/or temperature, evidence available up to around the year 2012 indicated impacts on pollen and mould/fungal spore production and atmospheric concentration, seasonality, allergenicity and spatial distribution (Table 1).

Several other recent reviews are also worthy of mention. The Intergovernmental Panel on Climate Change's latest assessment, the Fifth Assessment Report, has explicitly assessed the impacts of climate change on aeroallergens as one of a number of ecosystem-mediated impacts of climate change on health outcomes [3]. However, the short section devoted to this area does not cite or discuss a number of very significant studies that were published between the IPCC's Fourth and Fifth Assessment Reports, such as that by Wolf et al. [4] and Ziska et al. [5].

Takaro et al. [6] have conducted a general review of climate change and respiratory health, including allergic respiratory 
Table 1 Likely impacts of climate change on environmental allergens, by allergen characteristic and allergen "group"

\begin{tabular}{llllll}
\hline & & Allergen "group” & \\
\cline { 3 - 5 } & & Respiratory & Contact & Plant food & Insect \\
\hline \multirow{2}{*}{ Allergen characteristic } & Amount & $\uparrow$ & & \\
& Season & $\Delta$ & & $\Delta$ \\
& Spatial distribution & $\Delta$ & $\uparrow$ (poison ivy) & $?$ & $\Delta$ \\
& Allergenicity & $\uparrow$ & & \\
\hline
\end{tabular}

$\uparrow$ increase, $\Delta$ change, ? uncertain or theoretical diseases. Their review focused on papers published in peerreviewed academic journals in the 5 years prior to the publication of their paper in 2013 (their review only included two 2013 references, neither of which being relevant to climate change, allergens and allergic diseases). Of several interesting observations was that "Given the evidence, that the environmental health effects of climate change are underway and projected to increase in future, one can expect the body of scientific literature on climate change and respiratory health to grow rapidly" [6].

Beyond the above, Todea et al. [7] have provided a relatively brief general review of the topic, including consideration of the interactions between allergens and air pollution under climate change. Bajin et al. [8] provide a review focused on the impacts of climate change on pollen and related allergy in Asia Minor. Finally, Smith et al. [9] have conducted an extensive review of ragweed as an environmental health threat in Europe, including a section on climate change in which the research on climate change and plant distribution, ragweed pollen production and other aspects were discussed. However, an unfortunate omission from this review is the landmark paper by Singer et al. [10] demonstrating increasing Amb a 1 (ragweed's major allergen) content in common ragweed pollen as a function of rising atmospheric $\mathrm{CO}_{2}$ concentration.

\section{The Latest Research}

Research on the impacts of climate change on allergens and allergic diseases has accelerated in recent years. As one indicator of this, a research database search for literature on this topic ${ }^{1}$ results in 271 documents being identified, with the first two of these being published in 1998, and no less than 90 being published in just the last two and a half years or so (1 January 2013 to 21 May 2015) (Fig. 1). In other words, one third of the literature on this topic has been published in just the last two and a half years. Indeed, 2014 saw more documents published on this topic ( 47 in total) than in any previous year, and documents on this topic were cited more in 2014

\footnotetext{
${ }^{1}$ Thomson Reuters' Web of Knowledge, Web of Science search with topic terms "climate change" and "allerg*".
}

(746 citations in total) than in any previous year. Most of the research published in the last two and a half years or so has been in the broad research area of environmental sciences and ecology (Fig. 2), with the immunology, allergy and public environmental occupational health research areas also in combination making up a large portion of this research. These research foci have been reflected in the leading journals in which this research is published (Fig. 3). The following sections review research on this topic over the last two and a half years, since 1 January 2013.

\section{Pollen (and Fungal Spore) Amount}

Further studies have been added to the literature on the impacts of climate change on pollen production and atmospheric pollen (and fungal spore) concentrations. All studies have come from the Northern Hemisphere, including four from Europe, one from Japan and one from the USA.

The most recent and most important study in this area in the last two and a half years is that by Hamaoui-Laguel et al. [11]. This team projected the impacts of future climate and land-use changes on airborne ragweed pollen concentrations in Europe using two comprehensive modelling frameworks accounting for pollen production, release and atmospheric dispersion changes [11]. Their results showed that by 2050, airborne ragweed pollen concentrations will be approximately four times higher than they currently are (with an uncertainty range from 2 to 12) [11].

Cariñanos et al. [12] analysed 21 years (1991-2011) of airborne Amaranthaceae pollen records for an area located in the southern part of the Iberian Peninsula. A trend was noted towards increasingly early pollen peak dates and gradual decline in the annual Pollen Index over later years [12], with the latter attributed to increasing urbanisation of the area and a change in the rainfall distribution. Over a similar period and in a similar location, García-Mozo et al. [13] studied a 30-year (1982-2011) olive pollen record from Spain and found a trend towards increasing pollen production [13].

Zhang et al. [14] have developed a regional-scale pollen emission and transport modelling framework for investigating the impact of climate change on allergic airway disease and evaluated it for southern California. They noted that for this 
Fig. 1 Types of documents published on the topic of climate change and allerg* during the period 1 January 2013 to 21 May 2015. From Thomson Reuters' Web of Knowledge, Web of Science

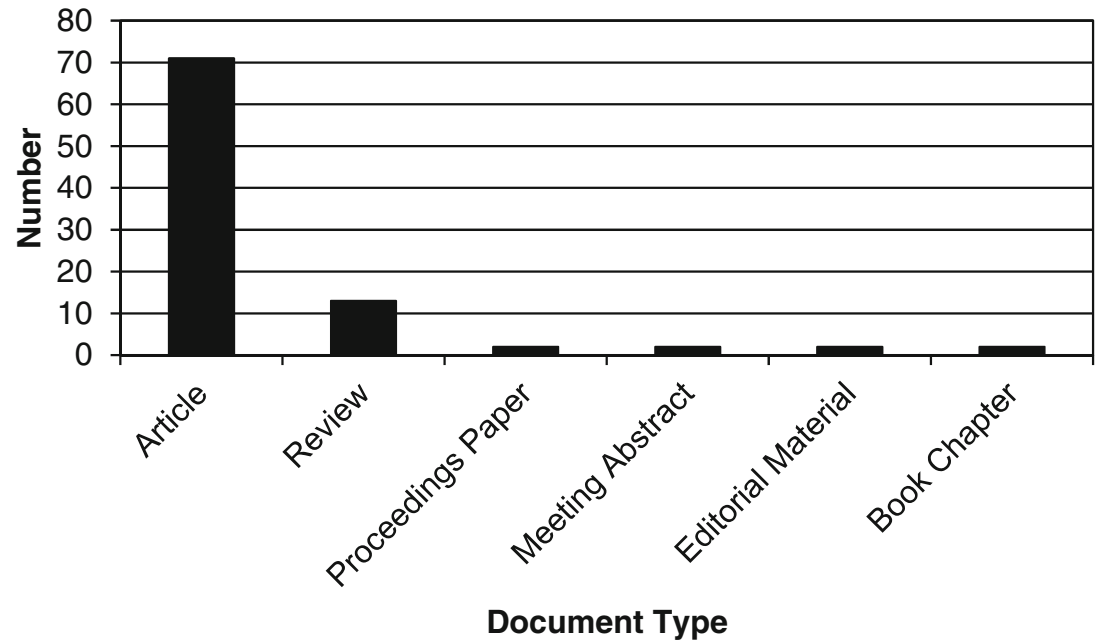

region, pollen seasons are projected to occur earlier but with $0.1-10 \%$ less pollen production by around 2050 compared to current as a result of higher temperatures and less precipitation [14].

Yamada et al. [15] have provided a current and in-depth review of Japanese cedar pollinosis in Japan. Amongst the causes of the dramatic rise in both airborne Japanese cedar pollen and Japanese cedar pollinosis over recent decades, they suggested climate change, and in particular temperature increases over this period in Japan.

Damialis et al. [16] examined atmospheric fungal spore concentrations in Thessaloniki, Greece, over the 19-year period 1987-2005, during which temperatures generally increased, and generally found decreasing concentrations over this period.

The above studies suggest that recent and future trends in pollen and fungal spore amounts associated with climate change vary from species to species and region to region. This is consistent with previous research in this area (e.g., Ziello et al. [17]). This emphasises the need for future research in this area to focus on species and regions that are yet to be studied, with perhaps the greatest need being in the Southern Hemisphere.

\section{Pollen Season}

Several studies in the last two and a half years have added to the already significant body of literature regarding the impacts of climate change on pollen season. Several of these have focused on the European region and in particular the Mediterranean (two studies from Italy and one from Spain; and one from the island of Guernsey in the English Channel). The other studies over this period had a US focus.

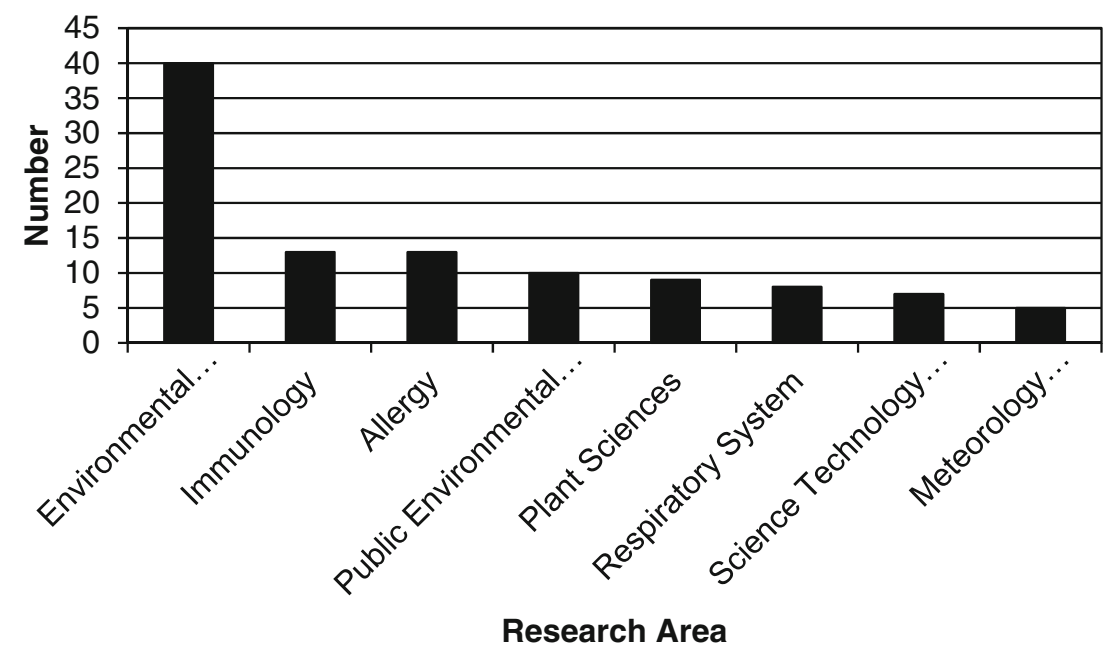

Fig. 2 The top eight broad research areas of documents published on the topic of climate change and allerg* during the period 1 January 2013 to 21 May 2015. Documents can have more than one research area. Abbreviated research areas on the $x$-axis are the following: Environmental... = Environmental Sciences Ecology; Public
Environmental... = Public Environmental Occupational Health; Science Technology $\ldots=$ Science Technology Other Topics; Meteorology $\ldots=$ Meteorology Atmospheric Sciences. From Thomson Reuters' Web of Knowledge, Web of Science 
Fig. 3 The top seven source (journal) titles of documents published on the topic of climate change and allerg* during the period 1 January 2013 to 21

May 2015. Abbreviated source titles on the $x$-axis are the following: Science of the Total Environment; Urban Forestry \& Urban Greening; The Journal of Allergy and Clinical Immunology; AAIR Allergy, Asthma \& Immunology Research. From Thomson Reuters' Web of Knowledge, Web of Science

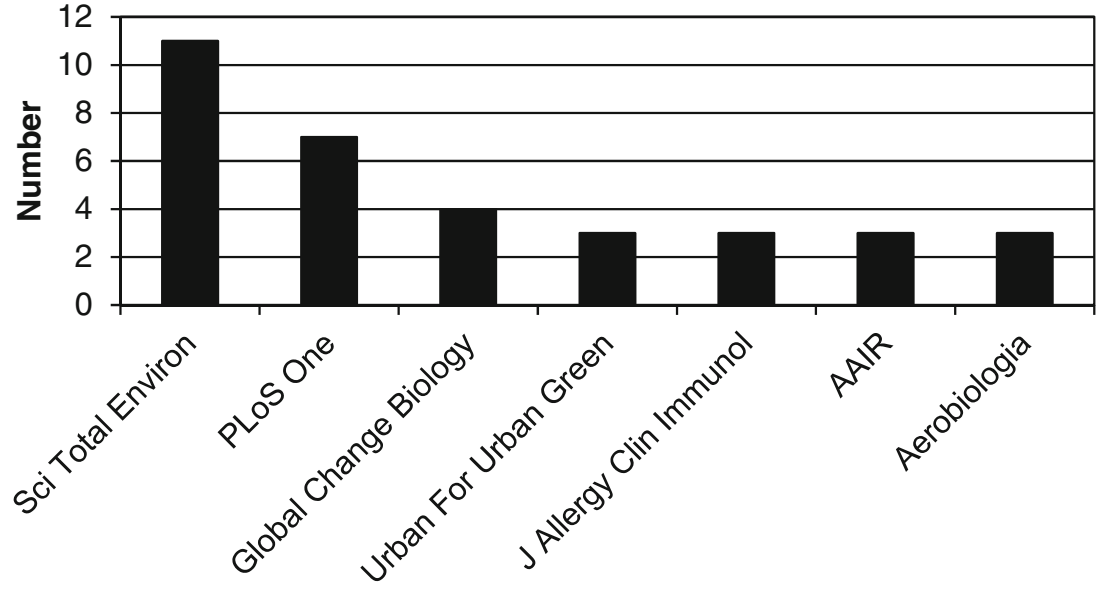

Source Title
García-Mozo et al. [13] studied a 30-year (1982-2011) olive pollen record from Spain and found a trend towards earlier pollen season start and peak date and delayed pollen season end [13]. Bonofiglio et al. [18] examined the impact of climate change on the olive pollen season in Italy and projected advances in the start date of about 20-30 days under a $3.4{ }^{\circ} \mathrm{C}$ warming by the year 2100 . Sposato et al. [19] studied cypress pollen seasonality in three regions of Italy over the two 3-year periods 1998-2000 and 2010-2012. They found that the cypress pollen concentration peak was delayed from February to March in 2010-2012 compared to 1998-2000 in central Italy (or had a more distinctive March peak in the case of northern Italy), with a shift in pollination towards spring [19].

The past two and a half years has seen four related studies published by a team centred on Zhang, Bielory, and Georgopoulos from Rutgers University in the USA. Zhang et al. [20] examined the impacts of climate change on birch and oak pollen seasons at six sites spread across the USA. They found that birch and oak trees were observed to flower 1-2 weeks earlier for the latter period 2001-2011 compared to the earlier period 1994-2000 [20]. This work was extended in Zhang et al. [21], which examined 50 US sites and five plant taxa (birch, oak, ragweed, mugwort and grass). On average, the allergenic pollen season for these five taxa started 3 days earlier during the decade 2001-2010 than in the 1990s (1994-2000) [21]. Focusing on several Northern Hemisphere locations, Zhang et al. [22] presented a Bayesian framework for modelling impacts of climate change on the start date of the birch pollen season and the date of the maximum daily birch pollen count and found that these will occur around 2 to 4 weeks earlier in the future [22]. More recent work by this team has focused on predicting the onset and duration of the airborne allergenic pollen season in the USA, again using a modelling framework [23].
An important study has been produced by the Chair of Ecoclimatology and Institute for Advanced Study at Technische Universität München: Bock et al. [24]. This team analysed first flowering date and flowering duration from a 27-year dataset (1985-2011) of weekly flower observations on 232 plant species from the island of Guernsey in the English Channel, which has warmed by $0.5{ }^{\circ} \mathrm{C}$ over this period [24]. They found not only a trend of significantly earlier flowering over time but also a highly significant shortening of flowering duration over time [24]. The potential benefit of shorter flowering (and therefore pollen season) duration of specific species to those with pollen allergies was suggested by the authors.

Park and Schwartz [25] have similarly analysed changes in flowering phenology. They used herbarium records for the southeastern USA, a humid subtropical environment, over the period 1951 to 2009 . They found early spring flowering significantly advanced in response to increases in early spring (March) temperature, but that plant species that flower in the late spring through to mid-summer exhibited significantly delayed flowering in response to higher February (late winter) temperatures [25]. As an explanation of the latter result, they suggested that "As this region experiences warmer conditions and shorter winter periods than the sites of most previous temperate phenological studies, it is possible that warmer conditions in February would be more likely to result in unfulfilled chilling requirements, thereby delaying flowering among species that flower in mid-season" [25].

It should also be highlighted that the Intergovernmental Panel on Climate Change's Fifth Assessment Report provides an assessment of the impacts of climate change on plant and animal phenology [26]. This current assessment is that many plant and animal species have shifted their seasonal activities in response to observed climate change over recent decades [26] and also that "they are doing so now in many regions and will continue to do so in response to projected future climate 
change" [26]. Earlier occurrence of spring events (spring advancement), such as flowering, is seen in hundreds of plant and animal species in many regions [26].

Further studies that have examined impacts of climate change on pollen include Deák et al. [27] who analysed trends of the pollen season duration, start and end, as well as the annual total pollen count and annual peak pollen concentration in Szeged, Southern Hungary, for the 11-year period 1997-2007, in the context of climate change. The findings varied by taxa, with, for example, significant changes in total annual pollen count mostly being increases (for Morus, Populus and Urtica), and the only significant changes in pollen season duration being increases for Poaceae and Urtica, the former due particularly to a later end to the Poaceae pollen season and the latter to an earlier start and later end to the Urtica pollen season.

\section{Environmental Allergen Spatial Distribution}

The last 2 years, and particularly 2014, has seen the emergence of a previously neglected area of climate change and allergen research, regarding the spatial distribution of allergens and allergen-producing organisms. Interestingly, all five of the articles published in this area focus on invasive species, and three of the five focus on ragweed, reflecting the importance of these with respect to both climate change impacts and allergic diseases.

The studies by Chapman et al. [28] and Storkey et al. [29] have examined the range/spatial distribution of ragweed ( $\mathrm{Am}$ brosia artemisiifolia) in the context of climate change. Both studies have used alternatives to or complements of correlative species distribution models, with the former using a temperature- and photoperiod-driven phenology model, and the latter using a process-based distribution model. Both models project northward shifts in the range margins and no change in the southern part of the range of this species in the Northern Hemisphere (North America [28] and Europe [28, 29]) with future climate change. Richter et al. [30], based on earlier work by several of the same authors, also modelled the spread of ragweed in the future under climate change but focused on the management of this species and resulting health and economic benefits. Their study area was Austria and southern Germany (Bavaria), and they used not only three climate scenarios but also different management scenarios and levels of management effort. They found that a carefully designed management plan consisting of survey and eradication can drastically reduce the spread of ragweed [30].

Monceau et al. [31] review the invasive yellow-legged hornet in Europe. They highlight that this species is potentially deadly to people allergic to it or to other cross-reacting venoms [31], and brief mention is made of attempts to evaluate expansion risk of this species under climate change.
Mazza et al. [32] provide an excellent and thorough overview of invasive species relevant to human health, including allergic diseases. Their overview encompasses respiratory and skin allergies as well as allergic reactions to stinging insects, and they conclude that the negative impacts of invasive species are expected to intensify in the near future due to climate change [32].

It should also be highlighted that the Intergovernmental Panel on Climate Change's Fifth Assessment Report provides an in-depth assessment of observed and projected-future shifts in species ranges [26]. This current assessment is that many plant and animal species have moved their ranges in response to observed climate change over recent decades [26] and also that "they are doing so now in many regions and will continue to do so in response to projected future climate change" [26].

\section{Pollen (and Fungal Spore) Allergenicity}

A series of studies on the impacts of climate change on pollen (and mould spore) allergenicity in the last two and a half years has added considerable weight to our understanding in this area. Perhaps most significantly, we now have experimental studies in which more than one variable is changed, providing an increasingly realistic picture of likely future changes in pollen allergenicity. El Kelish et al. [33] examined ragweed pollen allergenicity under elevated $\mathrm{CO}_{2}$ and drought stress. They found a strong up-regulation of "Amb a" transcripts under elevated $\mathrm{CO}_{2}$, drought stress and elevated $\mathrm{CO}_{2}$ plus drought stress conditions [33] and concluded that "This result clearly indicates that under expected global change conditions, the allergenicity of ragweed pollen may increase, thereby affecting human health" [33].

Albertine et al. [34] examined the impacts of elevated $\mathrm{CO}_{2}$ and ozone $\left(\mathrm{O}_{3}\right)$ concentrations projected to occur in the future on Timothy grass pollen and allergen production. They found that elevated $\mathrm{CO}_{2}$ concentration significantly increased the amount of grass pollen produced, even when levels of $\mathrm{O}_{3}$ (a plant growth and reproduction suppressor) were also elevated [34]. Elevated $\mathrm{O}_{3}$ significantly reduced the Timothy grass allergen protein concentration of the pollen, but the net effect of increasing pollen production with elevated $\mathrm{CO}_{2}$ indicated increased allergen exposure under elevated levels of both these gases [34].

Jin et al. [35] studied Japanese Hop pollen allergenicity in Korea through comparison of pollen samples from 1998 and 2009 and from urban and suburban environments. They found that the 2009 and urban pollen was more potent than the 1998 and suburban pollen, respectively. They attributed these increases in pollen allergenicity to the higher temperatures and $\mathrm{CO}_{2}$ concentration of the latter period and the urban environment.

Research from different sites across the greater area of Munich by Beck et al. [36] indicates that surface level ozone is a 
crucial factor leading to clinically relevant enhanced allergenicity of birch pollen [36]. However, although increased ozone production is generally projected with increasing temperatures, the net direct impact of climate change on ozone concentrations worldwide is now thought to be a reduction [3].

In Songnuan's [37] in-depth review of wind-pollination and the roles of pollen allergenic proteins, it was noted that with climate change and more extreme environmental conditions, the amounts of pathogenesis-related (PR) proteins in pollen are likely to increase (PR proteins are defence proteins that can be induced by abiotic stress). Several groups of PR proteins have been classified as allergens from pollen [37]. Songnuan [37] also stated that this "may partially account for the continuous increase in allergy incidences worldwide".

In addition to the above studies on climate change and pollen allergenicity is the recent study by Lang-Yona et al. [38] on the impacts of changes in atmospheric $\mathrm{CO}_{2}$ concentration on the allergenicity of the mould Aspergillus fumigatus. This team grew this fungus at six atmospheric $\mathrm{CO}_{2}$ concentrations, ranging from preindustrial $(280 \mathrm{ppm})$ to current $(392 \mathrm{ppm})$ to projected future $(560 \mathrm{ppm})$. They found that fungi grown under current $\mathrm{CO}_{2}$ levels exhibit 8.5- and 3.5 -fold higher allergenicity compared to fungi grown at preindustrial and projected future $\mathrm{CO}_{2}$ levels, respectively [38]. In other words, as noted by Lang-Yona et al. [38], it appears that there is an optimal $\mathrm{CO}_{2}$ concentration for the allergenicity of $A$. fumigatus at about $400 \mathrm{ppm}$. This would suggest that the maximum adverse health impact on allergy related to this particular fungus is with us now. The authors also highlight that even though their results show a decrease in allergenicity of $A$. fumigatus with further increase in $\mathrm{CO}_{2}$ concentration, future allergenicity is still higher than it was at preindustrial $\mathrm{CO}_{2}$ concentrations. This finding adds further weight to the Beggs-Bambrick climate changeasthma hypothesis [39].

\section{Allergic Diseases}

Beyond the research on the impacts of climate change on allergens reviewed above, the last two and a half years or so has seen the appearance of several studies on the impacts of climate change on allergic diseases themselves. Fuertes et al. [40] analysed data from the International Study of Asthma and Allergies in Childhood (ISAAC) Phase Three as a first step in assessing how climate change may affect allergic rhinitis symptoms. The analysis was of 222 centres in 94 countries for 13- to 14-year-olds and 135 centres in 59 countries for 6 - to 7 -year-olds, for which associations of rhinitis symptom prevalences with temperature, precipitation, vapour pressure and the normalised difference vegetation index were assessed [40]. The results suggested a general positive association of mean monthly temperature, vapour pressure and precipitation, with symptom prevalence, providing "suggestive evidence that climate (and future changes in climate) may influence rhinitis symptom prevalence" [40].

Salo et al. [41] have analysed the prevalence of allergic sensitisation in the USA using data from the National Health and Nutrition Examination Survey (NHANES) 2005-2006. In the context of the current review, the most relevant result is perhaps that showing a statistically significant and consistent increase in sensitisation of subjects aged 6 years and older to outdoor allergens in metropolitan areas with $\geq 1$ million population compared to other areas. This applied to sensitisation to the moulds Aspergillus and Alternaria, Bermuda grass and Rye grass, thistle and ragweed, and oak (but not birch). Amongst the suggested potential causes of this higher prevalence of allergic sensitisation in urban areas was reference to the higher temperature and $\mathrm{CO}_{2}$ concentration of urban areas and the associated increased pollen production of plants (specifically ragweed) in urban areas compared to rural (experimental research conducted by Ziska et al. [42]). Salo et al. [41] explicitly linked this higher allergic sensitisation in urban areas to climate change not only through this urban-rural analog of climate change but through the research on the impacts of climate change on pollen seasons, greater pollen loads, and changes in allergenicity and spatial distributions of allergens.

The last year or so has also seen two important contributions with regard to the impacts of climate change on contact allergy and dermatitis, one a review and the other an original field and laboratory study. In a broader review of the impacts of climate change on skin diseases, Balato et al. [43] devoted a section to allergic diseases. They highlight the fact that the skin is the most exposed organ to the environment and that it is therefore not surprising that cutaneous diseases are inclined to have a high sensitivity to climate [43]. Lawton et al. [44] report their research on the identification of a major causative agent of human cercarial dermatitis, the schistosome Trichobilharzia franki, in southern England. Human cercarial dermatitis is caused by an acute allergic reaction in the skin that develops as a result of repeated contact with water containing schistosomatid cercariae [44]. They also noted that climate change can impact on the bird host of the schistosome, by changing its distribution and migratory routes, "and thus enabling infected bird species to visit the UK, which may not have done so before" [44].

In a systematic review of the impacts of ambient humidity on child health, Gao et al. [45] assessed 37 papers, with $35 \%$ of these focused on allergic diseases, and another $32 \%$ on respiratory system diseases. While the review demonstrated that ambient humidity generally plays a significant role in the incidence and prevalence of childhood climate-sensitive diseases, especially respiratory system and allergic diseases, some inconsistencies in the direction and magnitude of the effects of ambient humidity warrant further research in this area. Nonetheless, the authors presented a compelling case 
for the link between changes in humidity related to climate change and significant impacts on child allergic diseases.

Bastl et al. [46] have developed a "symptom load index, to compare the severity of pollen seasons for pollen allergy sufferers during different seasons in different geographical regions". They examined the birch, grass and ragweed pollen seasons in Austria and Germany from 2009 to 2013 and demonstrated that the same amount of pollen induces different symptom levels in different years in different regions [46]. They included amongst the future applications of the symptom load index, monitoring the development of pollen allergy symptom severity in the context of climate change [46].

In contrast to the international and national studies described above is the small-scale clinical study by Kim et al. [47]. The study explored the clinical outcomes of allergenspecific immunotherapy in the context of climate change.

Beyond the above, a number of articles have included mention of climate change, allergens and allergic diseases (Apter [48]; D'Amato et al. [49]; De Sario et al. [50]; Green et al. [51]; Kim et al. [52]; Kinney et al. [53]; Ward et al. [54]).

\section{Adaptation}

Two recent studies have explored aspects of climate change adaptation with respect to allergens and allergic diseases. The two studies considered urban allergenic plant management and urban planting practices and policies, adaptation measures that had been developed earlier by Beggs [55]. Katz and Carey [56] conducted a study of the relationships between ragweed plant density, land use and ragweed pollen concentrations. Ragweed plant density and land use predicted a large portion of airborne ragweed pollen concentrations. They concluded that "management of allergenic pollen producing plants must be considered at multiple spatial scales" and "will become increasingly important over the coming decades, as temperatures and carbon dioxide concentrations continue to increase" [56]. Cheng and Berry [57] conducted a literature review of health co-benefits and risks of public health adaptation strategies to climate change, and their findings included that adaptation strategies that influence urban design (increased urban green space) pose a health risk of increased allergic diseases. This further emphasises the importance of good planning in the design of green spaces in urban areas.

\section{Monitoring}

Another important climate change adaptation strategy with respect to allergens and allergic diseases is enhanced aeroallergen monitoring and forecasting [55]. Recent research has developed this in various ways. Cecchi [58] has stated that "Future research should include the implementation of standard pollen count with allergen measurement as a proxy of exposure in epidemiological studies and clinical trials", highlighting that this is most important due to climate change [58]. A number of authors have also highlighted the need for continued and better resourcing of pollen monitoring networks. Cecchi [58] asserts that research both on allergenic pollen and national pollen networks should be continuously supported, while Beggs et al. [59] highlight the need for a national standardised pollen monitoring network in Australia.

Takaro et al. [6] take a more holistic view of monitoring in the context of climate change, aeroallergens and allergic respiratory diseases, stating that our ability to address important research questions in this area will be enhanced by establishing more finely resolved networks of daily pollen monitoring sites, "linked at comparable temporal and spatial scales to reporting networks for near real-time health tracking of allergy and asthma health effects, linked with carbon dioxide emission source data, and other health-relevant air pollutant monitoring" [6].

Finally, Fernández-Llamazares et al. [60] have also highlighted the potential role of airborne pollen monitoring and records in providing relevant data for the protection of plants and its potential applications to the management and conservation of plant diversity.

\section{Conclusions}

The surge of research on the impacts of climate change on allergens and allergic diseases over the last two and a half years reaffirms this impact as one of the most important impacts of climate change on human health. Particularly noteworthy is the research over the last two and a half years on the impacts of climate change on the spatial distribution of allergens and allergen-producing organisms, on pollen and fungal spore allergenicity, and on allergic diseases themselves. While a diversity of impacts is being revealed by this research, overall, the clear message is that the impacts of climate change on allergic diseases, mediated by impacts on environmental allergens, are and will continue to be adverse.

One of the striking features of the latest research on the impacts of climate change on allergens and allergic diseases (like the research that came before it) is that it is overwhelmingly from the Northern Hemisphere. One of the largest gaps in knowledge in this area is therefore what the past and future impacts of climate change on allergens and allergic diseases in the Southern Hemisphere are. Recent research in Australia [61] has started to lay the foundations for a long-term pollen monitoring network that would at least enable some of the questions relating to this part of the world to be answered.

Acknowledgments The author thanks two anonymous reviewers for their positive and constructive comments on the manuscript.

Conflict of Interest There is no conflict of interest. 


\section{References}

1. Beggs PJ. Impacts of climate change on aeroallergens: past and future. Clin Exp Allergy. 2004;34(10):1507-13. doi:10.1111/j. 1365-2222.2004.02061.x.

2. Beggs PJ. Impacts of climate change on allergens and allergic diseases: knowledge and highlights from two decades of research. In: Butler CD, editor. Climate change and global health. Wallingford: CAB International (CABI); 2014. p. 105-13.

3. Smith KR, Woodward A, Campbell-Lendrum D, Chadee DD, Honda Y, Liu Q, et al. Human health: impacts, adaptation, and co-benefits. In: Field CB, Barros VR, Dokken DJ, Mach KJ, Mastrandrea MD, Bilir TE, Chatterjee M, Ebi KL, Estrada YO, Genova RC, Girma B, Kissel ES, Levy AN, MacCracken S, Mastrandrea PR, White LL, editors. Climate change 2014: impacts, adaptation, and vulnerability. Part A: global and sectoral aspects. Contribution of Working Group II to the Fifth Assessment Report of the Intergovernmental Panel on Climate Change. Cambridge: Cambridge University Press; 2014. p. 709-54.

4. Wolf J, O’Neill NR, Rogers CA, Muilenberg ML, Ziska LH. Elevated atmospheric carbon dioxide concentrations amplify Alternaria alternata sporulation and total antigen production. Environ Health Perspect. 2010;118(9):1223-8. doi:10.1289/ehp. 0901867.

5. Ziska L, Knowlton K, Rogers C, Dalan D, Tierney N, Elder MA, et al. Recent warming by latitude associated with increased length of ragweed pollen season in central North America. Proc Natl Acad Sci U S A. 2011;108(10):4248-51. doi:10.1073/pnas.1014107108.

6. Takaro TK, Knowlton K, Balmes JR. Climate change and respiratory health: current evidence and knowledge gaps. Expert Rev Respir Med. 2013;7(4):349-61. doi:10.1586/17476348.2013. 814367.

7. Todea DA, Suatean I, Coman AC, Rosca LE. The effect of climate change and air pollution on allergenic potential of pollens. Not Bot Horti Agrobo. 2013;41(2):646-50.

8. Bajin MD, Cingi C, Oghan F, Gurbuz MK. Global warming and allergy in Asia Minor. Eur Arch Otorhinolaryngol. 2013;270(1): 27-31. doi:10.1007/s00405-012-2073-9.

9. Smith M, Cecchi L, Skjøth CA, Karrer G, Šikoparija B. Common ragweed: a threat to environmental health in Europe. Environ Int. 2013;61:115-26. doi:10.1016/j.envint.2013.08.005.

10. Singer BD, Ziska LH, Frenz DA, Gebhard DE, Straka JG. Increasing Amb a 1 content in common ragweed (Ambrosia artemisiifolia) pollen as a function of rising atmospheric $\mathrm{CO}_{2}$ concentration. Funct Plant Biol. 2005;32(7):667-70. doi:10.1071/ FP05039.

11. Hamaoui-Laguel L, Vautard R, Liu L, Solmon F, Viovy N, Khvorosthyanov D, et al. Effects of climate change and seed dispersal on airborne ragweed pollen loads in Europe. Nat Clim Change. 2015. doi:10.1038/NCLIMATE2652.

12. Cariñanos $\mathrm{P}$, Alcázar $\mathrm{P}$, Galán $\mathrm{C}$, Domínguez E. Environmental behaviour of airborne Amaranthaceae pollen in the southern part of the Iberian Peninsula, and its role in future climate scenarios. Sci Total Environ. 2014;470-471:480-7. doi:10.1016/j.scitotenv.2013. 10.024 .

13. García-Mozo H, Yaezel L, Oteros J, Galán C. Statistical approach to the analysis of olive long-term pollen season trends in southern Spain. Sci Total Environ. 2014;473-474:103-9. doi:10.1016/j. scitotenv.2013.11.142

14. Zhang R, Duhl T, Salam MT, House JM, Flagan RC, Avol EL, et al. Development of a regional-scale pollen emission and transport modeling framework for investigating the impact of climate change on allergic airway disease. Biogeosciences. 2014;11(6):1461-78. doi:10.5194/bg-11-1461-2014.
15. Yamada T, Saito H, Fujieda S. Present state of Japanese cedar pollinosis: the national affliction. J Allergy Clin Immunol. 2014;133(3):632-9. doi:10.1016/j.jaci.2013.11.002.

16. Damialis A, Vokou D, Gioulekas D, Halley JM. Long-term trends in airborne fungal-spore concentrations: a comparison with pollen. Fungal Ecol. 2015;13:150-6. doi:10.1016/j.funeco.2014.09.010.

17. Ziello C, Sparks TH, Estrella N, Belmonte J, Bergmann KC, Bucher E, et al. Changes to airborne pollen counts across Europe. PLoS One. 2012;7(4), e34076. doi:10.1371/journal.pone.0034076.

18. Bonofiglio T, Orlandi F, Ruga L, Romano B, Fornaciari M. Climate change impact on the olive pollen season in Mediterranean areas of Italy: air quality in late spring from an allergenic point of view. Environ Monit Assess. 2013;185(1):877-90. doi:10.1007/s10661012-2598-9.

19. Sposato B, Liccardi G, Russo M, Folletti I, Siracusa A, Scichilone $\mathrm{N}$, et al. Cypress pollen: an unexpected major sensitizing agent in different regions of Italy. J Invest Allergol Clin Immunol. 2014;24(1):23-8.

20. Zhang Y, Bielory L, Georgopoulos PG. Climate change effect on Betula (birch) and Quercus (oak) pollen seasons in the United States. Int J Biometeorol. 2014;58(5):909-19. doi:10.1007/ s00484-013-0674-7.

21. Zhang Y, Bielory L, Mi Z, Cai T, Robock A, Georgopoulos P. Allergenic pollen season variations in the past two decades under changing climate in the United States. Global Change Biol. 2015;21(4):1581-9. doi:10.1111/gcb.12755.

22. Zhang Y, Isukapalli SS, Bielory L, Georgopoulos PG. Bayesian analysis of climate change effects on observed and projected airborne levels of birch pollen. Atmos Environ. 2013;68:64-73. doi: 10.1016/j.atmosenv.2012.11.028.

23. Zhang Y, Bielory L, Cai T, Mi Z, Georgopoulos P. Predicting onset and duration of airborne allergenic pollen season in the United States. Atmos Environ. 2015;103:297-306. doi:10.1016/j. atmosenv.2014.12.019.

24. Bock A, Sparks TH, Estrella N, Jee N, Casebow A, Schunk C, et al. Changes in first flowering dates and flowering duration of 232 plant species on the island of Guernsey. Glob Change Biol. 2014;20: 3508-19. doi:10.1111/gcb.12579.

25. Park IW, Schwartz MD. Long-term herbarium records reveal temperature-dependent changes in flowering phenology in the southeastern USA. Int J Biometeorol. 2015;59(3):347-55. doi:10. 1007/s00484-014-0846-0.

26. Settele J, Scholes R, Betts RA, Bunn S, Leadley P, Nepstad D, et al. Terrestrial and inland water systems. In: Field CB, Barros VR, Dokken DJ, Mach KJ, Mastrandrea MD, Bilir TE, Chatterjee M, Ebi KL, Estrada YO, Genova RC, Girma B, Kissel ES, Levy AN, MacCracken S, Mastrandrea PR, White LL, editors. Climate change 2014: impacts, adaptation, and vulnerability. Part A: Global and sectoral aspects. Contribution of Working Group II to the Fifth Assessment Report of the Intergovernmental Panel on Climate Change. Cambridge: Cambridge University Press; 2014. p. 271-359.

27. Deák ÁJ, Makra L, Matyasovszky I, Csépe Z, Muladi B. Climate sensitivity of allergenic taxa in Central Europe associated with new climate change related forces. Sci Total Environ. 2013;442:36-47. doi:10.1016/j.scitotenv.2012.10.067.

28. Chapman DS, Haynes T, Beal S, Essl F, Bullock JM. Phenology predicts the native and invasive range limits of common ragweed. Glob Change Biol. 2014;20(1):192-202. doi:10.1111/gcb.12380.

29. Storkey J, Stratonovitch P, Chapman DS, Vidotto F, Semenov MA. A process-based approach to predicting the effect of climate change on the distribution of an invasive allergenic plant in Europe. PLoS One. 2014;9(2), e88156. doi:10.1371/journal.pone.0088156.

30. Richter R, Berger UE, Dullinger S, Essl F, Leitner M, Smith M, et al. Spread of invasive ragweed: climate change, management and 
how to reduce allergy costs. J Appl Ecol. 2013;50(6):1422-30. doi: 10.1111/1365-2664.12156.

31. Monceau K, Bonnard O, Thiéry D. Vespa velutina: a new invasive predator of honeybees in Europe. J Pest Sci. 2014;87(1):1-16. doi: 10.1007/s10340-013-0537-3.

32. Mazza G, Tricarico E, Genovesi P, Gherardi F. Biological invaders are threats to human health: an overview. Ethol Ecol Evol. 2014;26(2-3):112-29. doi:10.1080/03949370.2013.863225.

33. El Kelish A, Zhao F, Heller W, Durner J, Winkler JB, Behrendt H, et al. Ragweed (Ambrosia artemisiifolia) pollen allergenicity: SuperSAGE transcriptomic analysis upon elevated $\mathrm{CO}_{2}$ and drought stress. BMC Plant Biol. 2014;14:176. doi:10.1186/14712229-14-176.

34. Albertine JM, Manning WJ, DaCosta M, Stinson KA, Muilenberg ML, Rogers CA. Projected carbon dioxide to increase grass pollen and allergen exposure despite higher ozone levels. PLoS One. 2014;9(11), e111712. doi:10.1371/journal.pone.0111712.

35. Jin HJ, Choi GS, Shin Y-S, Kim J-H, Kim J-E, Ye Y-M, et al. The allergenic potency of Japanese Hop pollen is increasing with environmental changes in Korea. Allerg Asthma Immunol Res. 2013;5(5):309-14. doi:10.4168/aair.2013.5.5.309.

36. Beck I, Jochner S, Gilles S, McIntyre M, Buters JTM, SchmidtWeber C, et al. High environmental ozone levels lead to enhanced allergenicity of birch pollen. PLoS One. 2013;8(11), e80147. doi: 10.1371/journal.pone.0080147.

37. Songnuan W. Wind-pollination and the roles of pollen allergenic proteins. Asian Pac J Allergy Immunol. 2013;31(4):261-70. doi:10. 12932/AP0287.31.4.2013.

38. Lang-Yona N, Levin Y, Dannemiller KC, Yarden O, Peccia J, Rudich Y. Changes in atmospheric $\mathrm{CO}_{2}$ influence the allergenicity of Aspergillus fumigatus. Glob Change Biol. 2013;19(8):2381-8. doi:10.1111/gcb.12219.

39. Beggs PJ, Bambrick HJ. Is the global rise of asthma an early impact of anthropogenic climate change? Environ Health Perspect. 2005;113(8):915-9. doi:10.1289/ehp.7724.

40. Fuertes E, Butland BK, Anderson HR, Carlsten C, Strachan DP, Brauer M, et al. Childhood intermittent and persistent rhinitis prevalence and climate and vegetation: a global ecologic analysis. Ann Allergy Asthma Immunol. 2014;113(4):386-92. doi:10.1016/j. anai.2014.06.021.

41. Salo PM, Arbes Jr SJ, Jaramillo R, Calatroni A, Weir CH, Sever ML, et al. Prevalence of allergic sensitization in the United States: results from the National Health and Nutrition Examination Survey (NHANES) 2005-2006. J Allergy Clin Immunol. 2014;134(2): 350-9. doi:10.1016/j.jaci.2013.12.1071.

42. Ziska LH, Gebhard DE, Frenz DA, Faulkner S, Singer BD, Straka JG. Cities as harbingers of climate change: common ragweed, urbanization, and public health. J Allergy Clin Immunol. 2003;111(2):290-5. doi:10.1067/mai.2003.53.

43. Balato N, Megna M, Ayala F, Balato A, Napolitano M, Patruno C. Effects of climate changes on skin diseases. Expert Rev Anti Infect Ther. 2014;12(2):171-81. doi:10.1586/14787210.2014.875855.

44. Lawton SP, Lim RM, Dukes JP, Cook RT, Walker AJ, Kirk RS. Identification of a major causative agent of human cercarial dermatitis, Trichobilharzia franki (Müller and Kimmig 1994), in southern England and its evolutionary relationships with other European populations. Parasite Vect. 2014;7:277. doi:10.1186/1756-3305-7-277.

45. Gao J, Sun Y, Lu Y, Li L. Impact of ambient humidity on child health: a systematic review. PLoS One. 2014;9(12), e112508. doi: 10.1371/journal.pone.0112508.

46. Bastl K, Kmenta M, Jäger S, Bergmann K-C, EAN, Berger U. Development of a symptom load index: enabling temporal and regional pollen season comparisons and pointing out the need for personalized pollen information. Aerobiologia. 2014;30(3):269 80. doi:10.1007/s10453-014-9326-6.

47. Kim M-A, Yoon M-G, Jin H-J, Shin Y-S, Park H-S. Paradoxical increase of IgE binding components during allergen-specific immunotherapy in pollinosis patients. J Korean Med Sci. 2014;29(7): 1025-9. doi:10.3346/jkms.2014.29.7.1025.

48. Apter AJ. Advances in adult asthma diagnosis and treatment in 2012: potential therapeutics and gene-environment interactions. J Allergy Clin Immunol. 2013;131(1):47-54. doi:10.1016/j.jaci. 2012.11.020.

49. D'Amato G, Baena-Cagnani CE, Cecchi L, Annesi-Maesano I, Nunes C, Ansotegui I, et al. Climate change, air pollution and extreme events leading to increasing prevalence of allergic respiratory diseases. Multidisciplin Resp Med. 2013;8:12. doi:10.1186/ 2049-6958-8-12.

50. De Sario M, Katsouyanni K, Michelozzi P. Climate change, extreme weather events, air pollution and respiratory health in Europe. Eur Respir J. 2013;42(3):826-43. doi:10.1183/09031936. 00074712

51. Green RJ, Hockman M, Friedman R, Davis M, McDonald M, Seedat R, et al. Chronic rhinitis in South Africa: update 2013. S Afr Med J. 2013;103(6):419-22. doi:10.1796/SAMJ.6972.

52. Kim B-J, Lee S-Y, Kim H-B, Lee E, Hong S-J. Environmental changes, microbiota, and allergic diseases. Allergy Asthma Immunol Res. 2014;6(5):389-400. doi:10.4168/aair.2014.6.5.389.

53. Kinney PL, Sheffield PE, Weinberger KR. Climate, air quality, and allergy: emerging methods for detecting linkages. In: Pinkerton KE, Rom WN, editors. Global climate change and public health, respiratory medicine 7, New York; 2014. doi:10.1007/978-1-46148417-2 7.

54. Ward MDW, Copeland LB, Lehmann J, Doerfler DL, Vesper SJ. Assessing the allergenic potential of molds found in water-damaged homes in a mouse model. Inhal Toxicol. 2014;26(8):474-84. doi: 10.3109/08958378.2014.919043.

55. Beggs PJ. Adaptation to impacts of climate change on aeroallergens and allergic respiratory diseases. Int J Environ Res Public Health. 2010;7(8):3006-21. doi:10.3390/ijerph7083006.

56. Katz DSW, Carey TS. Heterogeneity in ragweed pollen exposure is determined by plant composition at small spatial scales. Sci Total Environ. 2014;485-486:435-40. doi:10.1016/j.scitotenv.2014.03. 099.

57. Cheng JJ, Berry P. Health co-benefits and risks of public health adaptation strategies to climate change: a review of current literature. Int J Public Health. 2013;58(2):305-11. doi:10.1007/s00038012-0422-5.

58. Cecchi L. From pollen count to pollen potency: the molecular era of aerobiology. Eur Respir J. 2013;42(4):898-900. doi:10.1183/ 09031936.00096413

59. Beggs PJ, Katelaris CH, Medek D, Johnston FH, Burton PK, Campbell B, et al. Differences in grass pollen allergen exposure across Australia. Aust NZ J Public Health. 2015;39(1):51-5. doi: 10.1111/1753-6405.12325.

60. Fernández-Llamazares Á, Belmonte J, Boada M, Fraixedas S. Airborne pollen records and their potential applications to the conservation of biodiversity. Aerobiologia. 2014;30(2):111-22. doi:10. 1007/s10453-013-9320-4.

61. Haberle SG, Bowman DMJS, Newnham RM, Johnston FH, Beggs PJ, Buters J, et al. The macroecology of airborne pollen in Australian and New Zealand urban areas. PLoS One. 2014;9(5), e97925. doi:10.1371/journal.pone.0097925. 